\title{
ISBD: Aid or Barrier to Understanding?
}

This article investigates the validity of claims that ISBD (International Standard Bibliographic Description) punctuation and conventions are a barrier to the understanding of catalog information. A group of undergraduate students were asked specific questions about the elements on catalog cards. Two sets of catalog entries were used for the test. The sets were identical in content, but one followed unrevised 1967 AACR chapter 6 rules and the other followed ISBD. The degree of correctness of the response and the response time were recorded. The test results showed a slightly greater degree and number in correctness of response to the ISBD format cards. The study indicates that the ISBD format aids, rather than hinders, reader understanding.

Secret punctuation [in ISBD descriptions]-like slashes, dashes and equal-signs-that only the "elect" can comprehend. ${ }^{1}$

\section{-Sanford Berman}

The day LC and ALA adopted ISBD was a sad day for public libraries. . . Latin abbreviations, the truncation of "illus." to "ill." and the introduction of a variety of esoteric punctuation marks may serve the needs of the LC and Berkeley user, but it [sic] will baffle the patrons of nonresearch libraries. $^{2}$

-Maurice J. Freedman

R EADING THESE and other, similiar quotations from the writings of respected members of the library profession caused us to think about the number of unsubstantiated claims and counterclaims that center on the ISBD (International Standard Bibliographic Description) conventions in cataloging. All developments in cataloging attract criticism founded on relevant and irrelevant concerns.

Even when concerns arising from fear of the Library of Congress or fear of change itself are discounted, there remains one constant theme in the criticisms of the ISBD. The theme is that articulated in the preced-

Michael Gorman is director, technical services departments, University Library, and Jami Hotsinpiller is visiting research associate, University of Illinois at Urbana-Champaign. ing quotations. Put simply, it is feared that the introduction of a new way of presenting descriptive information will create a major barrier to the understanding of that information by the "ordinary" catalog user.

As stated in the first standard edition of the International Standard Bibliographic Description (Monographs), the purpose of ISBD

is to provide an internationally accepted framework for the representation of descriptive information in bibliographic records. . . . It is designed to meet three requirements for the efficient international use of such records: first, that records produced in one country or by the users of one language can be easily understood in other countries and by the users of other languages; secondly, that the records produced in each country can be integrated into files or lists of various kinds containing also records from other countries; and thirdly, that records in written or printed form can be converted into machine-readable form with the minimum of editing.

To achieve these aims it was necessary to find a way by which the different elements making up a description could be recognized, by the eye or by a machine, without the need to understand the content. The means adopted is a prescribed system of punctuation. Within any one of the main areas of the description, each prescribed punctuation mark is a signal showing the nature of the element which follows it. ${ }^{3}$

The concern expressed for the "ordinary" catalog user is based on the premise that 
the punctuation and other conventions used before the introduction of the ISBD were understood by catalog users and that they had validity based on their inherent comprehensibility and their long use. Contrariwise, the ISBD punctuation and other conventions are viewed as "strange," "alien," "esoteric," and downright confusing.

We set out to test these beliefs. The purpose of our small project was simple. It was to try to discern the reality behind the rhetoric and to establish the truth or otherwise of the assertion that the ISBD punctuation and conventions prevented understanding of catalog information.

Our hypothesis, also, was simple. It was that there was no significant difference in understanding as between ISBD and nonISBD descriptions.

\section{METHOD}

Seventeen descriptions were prepared according to both sets of rules. Each description was typed on a three-by-five-inch card in the style of the unrevised $1967 \mathrm{AACR}^{4}$ chapter 6 and on another card following the ISBD conventions. ${ }^{5}$ Ten of the descriptions were in English. These ranged from simple descriptions to those containing such complexities as alternative and parallel titles. The other seven were in foreign languages. Three of these were in relatively accessible languages (French, Spanish, German), and four were in relatively inaccessible languages (Dutch, Afrikaans, Norwegian). (See appendix 1 for samples of these cards.) The descriptions were alone on the cards; that is, we did not add headings, holdings, class marks, etc.

Questions were devised to accompany the cards. Six of the cards had two questions, so there were a total of twenty-three questions (see appendix 2). The questions were straightforward in that there was a simple factual answer to each. Each question was designed to test the subject's understanding of the description. Typical questions were:

Who is the publisher?

In what city was this book published?

Is this book illustrated?

If you were recommending this book to a friend, what would you write down as the title?

The questions were put to randomly selected undergraduates using the University of Illinois Undergraduate Library. Each subject was handed four cards in turn and asked a question about each one. Undergraduate students were selected as constituting a group that could not be accused of being an elite, while having (we hoped) the basic reading and library use skills that one assumes the "average library user" possesses.

The ISBD and non-ISBD cards were interfiled in two sets, so that the first set consisted of the ISBD version of card 1, the non-ISBD version of card 2, the ISBD version of card 3, and so on, and the second set was a mirror image of the first. This ensured that each person questioned was asked questions relating to both ISBD and non-ISBD descriptions.

The questioner approached students at random and asked them if they would take part in a study by answering questions relating to catalog entries. All persons approached agreed to take part in the study. Whether this was due to their eagerness to help the library, general affability, or the Snickers candy bar each subject was given is not known. Only students were asked to participate. A total of twenty-two women and twenty-six men took part in the study. No attempt was made to question an equal number of women and men.

The questioner was equipped with a clipboard with an answer sheet. She also had a digital watch mounted on the clipboard to permit unobtrusive timing of the response. The questioner recorded the answers as correct, partially correct, and incorrect. The category of "partially correct" was added when it was realized that subjects sometimes gave too much information (including the correct answer) and sometimes gave only half of the answer. Next recorded was the time, in seconds, taken to answer each question.

As the cards were in a numbered series, the questioner knew which questions to ask, though she did not know which set was being used and did not look at the cards before handing them to the subjects, and so she was unaware of whether the card being examined was an ISBD card or non-ISBD card.

The study was carried out once as an ex- 
periment. Following this "dry run," some of the questions were rephrased and the method slightly changed. Once the changes were made, the final test was made. Each of the seventeen questions was asked eight times in the manner outlined above.

\section{RESULTS}

The full results of the project are given in appendixes 3 and 4 . Salient general points are:

1. The proportion of completely correct answers was slightly higher for the ISBD (68.5 percent) than for the non-ISBD $(64.1$ percent) descriptions.

2. The overall correctness of answers was higher for the ISBD descriptions (fifteen) than for the non-ISBD descriptions (seven). These figures were reached by comparing the number of correct answers and, when these were equal, comparing the number of partially correct answers (see appendix 3). Six questions were answered equally correctly or incorrectly for both.

3. The proportion of incorrect answers was substantially lower for the ISBD $(9.8$ percent) than for the non-ISBD (17.4 percent) descriptions.

4. The average response time for the ISBD descriptions (eight seconds) was slightly shorter than for the non-ISBD descriptions (nine seconds).

5. No areas of the description revealed a markedly different level of understanding as between the ISBD and non-ISBD conventions.

\section{CONCLUSION}

The study demonstrates to our satisfaction that the primary problem in reader use of the descriptive data in catalog entries lies in the nature of that data, not in the manner in which it is presented. Further, that a systematic set of conventions, such as those embodied in the ISBD, will aid rather than hinder reader understanding. The pre-ISBD conventions were an uneasy combination of normal prose usage and arbitrary convention. The ISBD conventions have the merits of system and consistency.

It seems to us that our study could be criticized on two grounds: first, that the sample was too small, and, second, that undergraduate students at a large university are not a fair example of "typical" catalog users.

We are confident that doubling the size of the study would not have markedly altered the results. The tendencies exhibited by the results are too strong to be capable of falsification by further sampling. On the other hand, we would welcome the use of the method (or a variant of it) to examine the problem more extensively.

The second potential criticism, the use of undergraduate students, has more apparent force. We have concluded that the level of literacy and understanding among undergraduates is not abnormally high and that any users of libraries with markedly less literacy and understanding could not use any type of catalog entry.

This may lead to the conclusion that, in many library environments, the conventional catalog entry description is largely useless. This may be so, and the proposition merits further study. Our study, on the other hand, was based on exploring alternatives in the context of conventional cataloging.

If, as we believe, the study proves that the ISBD aids, rather than halts, the understanding and speed of use of descriptive data as compared with pre-ISBD descriptions, then the long-drawn-out "controversy" over the ISBD is at an end. Critics of conventional cataloging can concentrate their attacks on the real problems (silly subject headings, unsought author headings, and lack of reader orientation) rather than the "unproblem" that we believe ISBD always has been.

On an unscientific note, we must report that three of the subjects, upon having the idea of the project explained to them after they had answered the questions, asked something to the effect of "since the new way [ISBD] is obviously more understandable, why are you bothering to do the study at all?" No one expressed a contrary opinion.

\section{REFERENCES}

1. Sanford Berman, "The Cataloging Shtik," Library Journal 102:1251-53 (June 1, 1977).

2. Maurice J. Freedman, "Public Libraries, the Library of Congress, and the National Biblio- 
graphic Network," Library Journal 102:221119 (Nov. 1, 1977).

3. ISBD $(M)$. 1st standard ed. (London: IFLA Office for UBC, 1974), p.vii.

4. Anglo-American Cataloging Rules. North American Text (Chicago: American Library Assn., 1967).
5. Anglo-American Cataloging Rules. North American Text. Chapter 6: "Separately Published Monographs ... . Revised to Accord with the International Standard Bibliographic Description (Monographs)" (Chicago: American Library Assn., 1974).

APPENDIX 1

Examples of Cards USED in Test

Women as a force in history. A study in traditions and realities, [by] Mary R. Beard. New York, Octagon Books, 1976, c 1946.

382 p. $19 \mathrm{~cm}$.

Reprint of the ed. published by Macmillan, New York.

Bibliography: p. 341-369.

Includes index.

Women as a force in history : a study in traditions and realities / Mary R. Beard. -New York : Octagon Books, 1976, c1946.

382 p. ; $19 \mathrm{~cm}$.

Reprint of the ed. published by Macmillan, New York.

Bibliography: p. 341-369.

Includes index. 
Handbook of food expenditures, prices, and consumption. Guide de 1 a consommation, des dépenses et des prix alimentaires, [by] Zuhair A. Hassan, Danielle Champagne. Ottawa, Communications Unit, Economic Branch, Agriculture Canada, 1975.

$\mathrm{x}, 87 \mathrm{p} .28 \mathrm{~cm}$.

English and French.

Includes bibliographical references.

Handbook of food expenditures, prices, and consumption $=$ Guide de $1 \mathrm{a}$ consommation, des depenses et des prix alimentaires / Zuhair A. Hassan, Danielle Champagne. -- Ottawa :

Communications Unit, Economic Branch, Agriculture Canada, 1975.

$\mathrm{x}, 87 \mathrm{p}$. ; $28 \mathrm{~cm}$.

English and French.

Includes bibliographical references.

Diese oder eine andere Republik? By Otto B. Roegele. Köln, Walter-Raymond-Stif tung, 1974.

63 p. $19 \mathrm{~cm}$. (Kleine Reihe - WalterRaymond-Stiftung, Heft 8) 
Diese oder eine andere Republik? / Otto B. Roegele. -- Köln : Walter-RaymondStiftung, 1974 .

63 p. ; $19 \mathrm{~cm}$. -- (Kleine Reihe - WalterRaymond-Stiftung ; Heft 8)

Bibliographie van den Vlaamschen taalstrijd, door Th. Coopman en Jan Broeckaert. Gent, A. Siffer, 1904 .

320 p. $251 / 2 \mathrm{~cm}$.

Bibliographie van den Vlaamschen taalstrijd / door Th. Coopman en Jan Broeckaert. -- Gent : A. Siffer, 1904. 320 p. ; $26 \mathrm{~cm}$. 
APPENDIX 2

QUESTIONS USED IN TEST

1. Who is the publisher?.

2. If you were recommending this book to a friend, what would you write down as the title?

3. Who is the author?

4. If you were recommending this book to a friend, what would you write down as the title? 4a. Who is the publisher?

5. If you were recommending this book to a friend, what would you write down as the title? 5a. Who wrote this book?

6. In what city was this book published?

6a. Is it illustrated?

7. What is the subtitle?

8. Who is the author?

9. In what city was this book published?

10. Who is the publisher?

11. If you were recommending this book to a friend, what would you write down as the title?

12. Who is the author?

12a. In what city was this book published?

13. Who is the publisher?

14. Who is the author?

14a. Is this book illustrated?

15. In what city was this book published?

15a. Who is the publisher?

16. Who is the publisher?

17. Who is the publisher?

APPENDIX 3

ACCURACY OF RESPONSE

\begin{tabular}{|c|c|c|c|c|c|c|c|c|}
\hline Question & $\mathrm{C}^{*}$ & $\underset{P}{\text { ISBD }}$ & I & C & $\underset{P}{\text { Non-ISBD }}$ & I & $\begin{array}{l}\text { Subject of } \\
\text { Question }\end{array}$ & $\begin{array}{l}\text { Language } \\
\text { of Item }\end{array}$ \\
\hline 1. & 2 & 2 & - & 1 & 1 & 2 & Publisher & English \\
\hline 2. & 2 & 2 & - & 4 & - & - & Title & French \\
\hline 3. & 4 & - & - & 3 & 1 & - & Author & Norwegian \\
\hline 4. & 4 & - & - & 2 & 2 & - & Title & English \\
\hline $4 a$. & 2 & 1 & 1 & 3 & 1 & - & Publisher & English \\
\hline 5. & 1 & 3 & - & 1 & 3 & - & Title & English/French \\
\hline 5 a. & 2 & 2 & - & 4 & - & - & Author & English/French \\
\hline 6. & 1 & 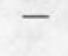 & 3 & - & - & 4 & $\begin{array}{l}\text { Place of } \\
\text { publication }\end{array}$ & Norwegian \\
\hline $6 a$. & 3 & - & 1 & 4 & - & - & Illustrations & Norwegian \\
\hline 7. & - & 4 & - & 2 & 2 & - & Subtitle & English \\
\hline 8. & 4 & - & - & 4 & - & - & Author & English \\
\hline 9. & 4 & - & - & 2 & - & 2 & $\begin{array}{l}\text { Place of } \\
\text { publication }\end{array}$ & German \\
\hline 10. & 3 & - & 1 & 2 & 1 & 1 & Publisher & Dutch \\
\hline 11. & 2 & 2 & - & 2 & 2 & - & Title & English \\
\hline 12. & 4 & - & - & 4 & - & - & Author & English \\
\hline $12 \mathrm{a}$. & 3 & - & 1 & 2 & - & 2 & $\begin{array}{l}\text { Place of } \\
\text { publication }\end{array}$ & English \\
\hline 13. & 4 & - & - & 4 & - & - & Author & English \\
\hline 14. & 4 & - & - & 4 & - & - & Author & Spanish \\
\hline 14a. & 4 & - & - & 4 & - & - & Illustrations & Spanish \\
\hline 15. & 1 & 3 & - & 3 & 1 & - & Place of & Afrikaans \\
\hline $15 \mathrm{a}$. & 3 & - & 1 & 3 & 1 & - & Publisher & Afrikaans \\
\hline 16. & 3 & 1 & - & 1 & 1 & 2 & Publisher & English \\
\hline 17. & 3 & - & 1 & 1 & - & 3 & Publisher & English \\
\hline TOTALS & 63 & 20 & 9 & 59 & 17 & 16 & & \\
\hline PERCENTAGE & 68.5 & 21.7 & 9.8 & 64.1 & 18.5 & 17.4 & & \\
\hline
\end{tabular}

${ }^{\circ} \mathrm{C}=$ Correct; $\mathrm{P}=$ Partially correct; $\mathrm{I}=$ Incorrect. 
526 / College d Research Libraries $\cdot$ November 1979

APPENDIX 4

RESPONSE TIME

\begin{tabular}{|c|c|c|c|c|}
\hline Correctness ${ }^{*}$ & Number & $\begin{array}{c}\text { ISBD } \\
\text { Average Response } \\
\text { Time (secs) } \dagger\end{array}$ & $\begin{array}{c}\text { Non-ISBD } \\
\text { Average Response } \\
\text { Time (secs) }\end{array}$ & $\begin{array}{c}\text { Difference } \\
\text { (secs) }\end{array}$ \\
\hline+ & 1. & 15 & 16 & +1 \\
\hline- & 2. & 11 & 17 & +6 \\
\hline+ & 3. & 6 & 8 & +2 \\
\hline+ & 4. & 6 & 8 & +2 \\
\hline- & $4 a$. & 4 & 8 & +4 \\
\hline 0 & 5. & 13 & 6 & -7 \\
\hline- & 5 a. & 7 & 5 & -2 \\
\hline+ & 6. & 20 & 18 & -2 \\
\hline- & $6 a$. & 4 & 3 & -1 \\
\hline - & 7. & 8 & 9 & +1 \\
\hline 0 & 8. & 3 & 6 & +3 \\
\hline+ & 9. & 14 & 12 & -2 \\
\hline+ & 10. & 5 & 12 & +7 \\
\hline 0 & 11. & 8 & 5 & -3 \\
\hline 0 & 12. & 2 & 3 & +1 \\
\hline+ & $12 a$. & 3 & 9 & +6 \\
\hline+ & 13. & 3 & 8 & +5 \\
\hline 0 & 14. & 5 & 6 & +1 \\
\hline 0 & $14 a$. & 4 & 8 & +4 \\
\hline- & 15. & 5 & 6 & +1 \\
\hline- & $15 a$. & 6 & 6 & 0 \\
\hline+ & 16. & 15 & 20 & +5 \\
\hline+ & 17. & 9 & 8 & -1 \\
\hline TOTAL & & 176 & 207 & 15 quicker \\
\hline AVERAGE & & 8 & 9 & responses from \\
\hline RESPONSE & & & & ISBD descriptions \\
\hline
\end{tabular}

$+=$ ISBD more correct; 0 = Equal correctness; - = Non-ISBD more correct.

$\uparrow$ All calculations to nearest second. 